\title{
An Index of Publisher Quality for the Academic Library
}

\section{John Calhoun and James K. Bracken}

Any subject bibliographer who has selected books from magazine reviews, like those in Choice, or from approval slips, like those in Baker \& Taylor's program, knows the difficulty of identifying the best books from among the many described as "immensely useful," "essential," or "indispensable" - or not described at all. Ensuring the purchase of only those books which will eventually be included in Choice's annual "Outstanding Academic Books" list (hereinafter simply OAB) would require either monitoring all of the reviews and ordering only those which are highly recommended, or waiting until the list appears and making purchases retrospectively - and neither alternative is particularly attractive. Fortunately, however, one of the easily apprehensible features included in both the reviews and the slips is the name of the publisher, and once a bibliographer recognizes that certain publishers produce more $\mathrm{OAB}$ titles than others, monitoring the reviews or slips becomes a much easier task.

With a little effort, it is possible to construct a list of the sixty most often appearing $\mathrm{OAB}$ publishers from Choice, and the figures on the left side of the ratios in column 1 of table 1 show the average number of titles placed by those publishers on the five most recently available lists. ${ }^{1}$ It is also possible to construct a list of the total number of titles published by each of the same firms from the "US Book Publishers" chapter in Literary Market Place, and the figures on the right of the ratios in column 1 show the average number of total titles per year during the same five-year period (except when followed by a smaller figure in parentheses, which indicates the number of years data was reported during that period). ${ }^{2}$ By combining the figures of column 1 to form a ratio, a measurement of publisher quality (at least as seen by this one review source) can be compiled, and we give that measurement as a simple ratio in column 2 .

The correlation of data from the two lists produces a qualitative measurement for only the five most recent years. Certainly the $\mathrm{OAB}$ titles, as well as the much larger number of total titles from any given publisher, fluctuates from one year to the next so that some publishers of quality may not be represented (especially when, like Addison-Wesley, they neglect to report total titles in Literary Market Place). Still, certain publishers seem to appear on the $\mathrm{OAB}$ lists more frequently than others: Harvard, with 18 OAB titles in 1981, also had 18 in 1980, 16 in 1979, 14 in 1978, and 18 in 1977; while Prentice-Hall, a much larger publisher, with 10 in 1981, had only 6 in 1980, 9 in 1979, 6 in 1978, and 8 in 1977. On this basis we believe that it is reasonable to conclude that the proportion of a publisher's $\mathrm{OAB}$ titles to its total titles is relatively constant-that is, a trustworthy guide to how much of the job has already been done for us by a rigorous editorial staff. To make the ratios a little more comprehensible, we have assigned an indexing value of 1.0 to the $1: 22.7$ figure enjoyed by both Oxford and Cambridge, two old and respected academic publishers that most subject bibliographers feel they "'know," and have computed corresponding figures for the other publishers in column 3.

Basic Books and Free Press produce $\mathrm{OABs}$ at about twice the frequency of $\mathrm{Ox}$ ford and Cambridge; and Cornell, Harvard, Indiana, Princeton, Temple, and Yale do even better than that. A "blind" purchase by any of these publishers is lia-

John Calhoun is technical services librarian, and James K. Bracken is readers services librarian, Seymour Library, Knox College, Galesburg, Illinois. 
TABLE 1

\begin{tabular}{|c|c|c|c|c|c|}
\hline & I & & II & III & IV \\
\hline Academic & $12.0: 560$ & & 1.46 .67 & .49 & 60 \\
\hline Ballinger & $2.0: 81$ & & 1.40 .50 & .56 & 6 \\
\hline Barnes \& Noble & $2.4: 91$ & & 1:38.08 & .60 & 25 \\
\hline Basic & $5.8: 64$ & & $1: 10.97$ & 2.07 & $19(+13)$ \\
\hline California & 15.6:197 & & $1: 12.63$ & 1.80 & 57 \\
\hline Cambridge & $18.6: 425$ & & $1: 22.85$ & 1.00 & 115 \\
\hline Chicago & $11.4: 212$ & & $1: 18.63$ & 1.22 & 64 \\
\hline Columbia & $8.8: 103$ & & $1: 11.66$ & 1.93 & 42 \\
\hline Cornell & $8.0: 83$ & & $1: 10.35$ & 2.20 & $33(+12)$ \\
\hline Doubleday & $5.0: 616$ & & $1: 123.21$ & .18 & $42(-15)$ \\
\hline Free & $6.2: 70$ & (3) & $1: 11.29$ & 2.02 & $18(+17)$ \\
\hline Freeman & $3.0: 55$ & & $1: 18.27$ & 1.25 & 22 \\
\hline Fortress & $2.0: 53$ & & $1: 26.40$ & .86 & 1 \\
\hline Gale & $3.6: 125$ & & $1: 34.61$ & .66 & 40 \\
\hline Greenwood & $6.0: 565$ & & 1:94.17 & .24 & $82(-49)$ \\
\hline Hall & $3.6: 447$ & & $1: 124.28$ & .18 & 48 \\
\hline Halsted & $5.2: 277$ & & $1: 55.07$ & .43 & 14 \\
\hline Harper \& Row & 7.6:1078 & & 1:141.84 & .16 & $72(-30)$ \\
\hline Harvard & $16.8: 113$ & & $1: 6.73$ & 3.38 & $78(+15)$ \\
\hline Holmes \& Meier & $2.6: 102$ & & $1: 39.23$ & .58 & 16 \\
\hline Humanities & $2.6: 215$ & & $1: 88.69$ & .28 & 22 \\
\hline Illinois & $3.2: 51$ & & $1: 15.94$ & 1.43 & 23 \\
\hline Ind & $7.0: 75$ & & $1: 11.09$ & 2.40 & $26(+12)$ \\
\hline is Hopkins & $6.4: 97$ & & $1: 15.13$ & 1.59 & 38 \\
\hline$y$-Bass & $2.8: 75$ & & $1: 26.79$ & .85 & 3 \\
\hline Knopf & $9.2: 138$ & & $1: 15.04$ & 1.51 & 48 \\
\hline igton & $2.8: 157$ & & $1: 56.14$ & .41 & 19 \\
\hline Little, Brown & $5.4: 297$ & & $1: 55.07$ & .41 & 33 \\
\hline McGraw-Hill & $5.2: 800$ & (1) & $1: 153.85$ & .15 & $40(-10)$ \\
\hline Minnesota & $2.4: 43$ & & $1: 17.75$ & 1.28 & 15 \\
\hline MIT & $4.0: 101$ & & $1: 25.30$ & .90 & 35 \\
\hline New York & $2.6: 58$ & & $1: 22.23$ & 1.02 & 9 \\
\hline North Carolina & $3.2: 42$ & & $1: 13.00$ & 1.64 & 15 \\
\hline Norton & $7.0: 269$ & & $1: 38.40$ & .59 & 44 \\
\hline Oxford & $29.2: 661$ & & $1: 22.64$ & 1.00 & 150 \\
\hline Pantheon & $3.2: 78$ & & $1: 24.25$ & .94 & 21 \\
\hline Pergamon & $3.4: 345$ & & 1:101.47 & .22 & 44 \\
\hline Plenum & $3.8: 315$ & & $1: 82.89$ & .27 & 23 \\
\hline Praege & $3.4: 194$ & & $1: 56.94$ & .40 & 23 \\
\hline Prentice-Hall & $7.8: 1200$ & (2) & $1: 153.85$ & .15 & $58(-14)$ \\
\hline Princeton & $16.8: 146$ & & $1: 8.67$ & 2.62 & $88(+5)$ \\
\hline & $2.8: 226$ & & $1: 80.64$ & .28 & 11 \\
\hline Random House & $4.0: 543$ & & $1: 135.85$ & .17 & $44(-22)$ \\
\hline Routledge \& Kegan Paul & $4.8: 240$ & (1) & $1: 50.00$ & .46 & 34 \\
\hline Rowman \& Littlefield & $3.2: 95$ & (4) & $1: 29.69$ & .77 & 11 \\
\hline Sc & $4.0: 102$ & & $1: 25.40$ & .90 & 27 \\
\hline bner & $3.4: 329$ & & $1: 96.76$ & .24 & 21 \\
\hline hern Illinois & $2.4: 45$ & & $1: 18.58$ & 1.22 & 15 \\
\hline Springer-Verlag & $4.4: 328$ & & $1: 74.55$ & .31 & 40 \\
\hline St. Martin's & 6.6 .459 & & $1: 69.55$ & .33 & 63 \\
\hline Temple & $2.8: 25$ & & $1: 8.93$ & 2.55 & $13(+13)$ \\
\hline Texas & $3.2: 56$ & & $1: 17.50$ & 1.30 & 13 \\
\hline Thames \& Hudson & $2.8: 33$ & (4) & 1:11.79 & 1.93 & 6 \\
\hline Twayne & $3.2: 122$ & & $1: 38.19$ & .60 & $119(-101)$ \\
\hline Van Nostrand & $3.4: 284$ & & $1: 83.53$ & .27 & 8 \\
\hline Viking & $4.2: 172$ & & $1: 40.90$ & .56 & 37 \\
\hline Westview & $3.4: 187$ & & $1: 58.44$ & .39 & 34 \\
\hline Wiley & 12.2:779 & & $1: 63.87$ & .36 & 72 \\
\hline Wisconsin & $2.6: 36$ & & 1:13.85 & 1.64 & 10 \\
\hline Yale & $10.6: 97$ & & 1:9.11 & 2.50 & $40(+19)$ \\
\hline
\end{tabular}


ble to be a pretty good bet. Doubleday, Harper \& Row, McGraw-Hill, PrenticeHall, and Random House (the big trade publishers), on the other hand, are such poor bets (in this league) that a subject bibliographer is well advised to have a convincing review in hand before selecting a title.

When we examine our own purchases over an average year (given here as column 4), we find convincing evidence which suggests we should be buying more of the first group and less of the second (exactly how many titles, based on what we were willing to buy from Oxford and Cambridge, we suggest in parentheses). We also find convincing evidence suggesting that some of our buying habits have become so calcified that they have produced bibliographical fossils reminiscent of the Jurassic Age: our Greenwood and Twayne purchases are the dinosaurs of a primeval era in acquisitions.

\section{REFERENCES}

1. "Outstanding Academic Books 1981," Choice 19, no. 9 (May 1982): 1184-1200; "Outstanding Academic Books 1980," Choice 18, no. 9 (May 1981): 1206-1226; "'Outstanding Academic Books 1979," Choice 17, no. 3 (May 1980): 331-52; "Outstanding Academic Books 1978," Choice 16, no. 3 (May 1979): 335-55; “'Outstanding Academic Books 1977," Choice 15, no. 3 (May 1978): 339-62.

2. "US Book Publishers," Literary Market Place with Names \& Numbers 42 (1982): 1-143; "US Book Publishers," Literary Market Place with Names \& Numbers 41 (1981): 1-137; " US Book Publishers," Literary Market Place with Names \& Numbers 40 (1980): 1-135; "US Book Publishers," Literary Market Place with Names \& Numbers 39 (1979): 1-126; "US Book Publishers," Literary Market Place with Names \& Numbers 38 (1978): 1-117.

LONGMAN INTRODUCES ...

\section{A MOST EFFICIENT GUIDE TO STATISTICAL INFORMATION . . .}

\section{DATAMAP}

\section{Index of Published Tables of Statistical Data}

Jarol B. Manheim and Allison Ondrasik

When researchers need to know quickly if the statistical information they're looking for is available, DATAMAP has the answer. - Researchers consulting DATAMAP find out immediately both if the statistic is available - and exactly where it can be found. - DATAMAP indexes over 10,000 statistical tables in twenty-eight of the most widely-held, and most widely-used reference publications:

Agricultural Statistics - Annual Survey of Manufactures - Business Statistics/Survey of Current Business * County and City Data Book * Congressional District Data Book * Condition of Education * Criminal Justice Statistics - Characteristics of the Population, U.S. Summary - Compendium of Social Statistics * Commodity Yearbook - Digest of Educational Statistics * Handbook of Labor Statistics * Health-United States - International Financial Statistics Yearbook • Information Please Almanac . Minerals Yearbook - Municipal Yearbook - National Transportation Statistics * Projections of

Educational Statistics - Statistical Abstract of the United States - Social Indicators - Statistical Yearbook * Uniform Crime Reports - UNESCOStatistical Yearbook • World Almanac - World Economic Survey • World Handbook of Political and Social Indicators * Yearbook of International Trade Statistics .

AND DATAMAP IS EASY TO USE. Although DATAMAP uses computerized database management, researchers do not need technical knowledge to consult DATAMAP. One simply refers to the topical index. If the statistic is available, the index sends the researcher to the exact page number in the volume where the statistic can be found. - If you compare DATAMAP with other statistical guides, you'll find this is an exceptionally useful index that is surprisingly inexpensive.

June 1983. 1200 pages (approx.) ISBN: 582-28304-3 hardcover \$175.00 (tent.) 


\section{Scholar's Guide to Intelligence Literature: Bibliography of the Russell J. Bowen Collection}

Why do we need a bibliography on intelligence? Because in the years since World War II intelligence has played an increasingly important role in shaping both the foreign policy and the defense policy of the United States and other major nations. Moreover, as the role of intelligence in diplomatic and strategic decisionmaking has become more prominent, more institutionalized, and more public, the literature on intelligence has become vast and varied. Our new Scholar's Guide to Intelligence Literature, prepared under the auspices of the National Intelligence Study Center, is the first book-length bibliography on intelligence and thus provides to librarians and researchers a valuable reference work with which to survey some of the many thousands of titles on intelligence.

Based on the Russell J. Bowen collection of intelligence literature now deposited at Georgetown University, the bibliography covers more than 5,000 titles. The broad scope of the collection is indicated by the 372 headings and subheadings in the bibliography: national intelligence establishments, clandestine operations, espionage, reconnaissance, ciphers and codes, research and analysis, counterintelligence, covert action, subversion, interrogation techniques, psychological warfare, unconventional warfare, and many more. Arranged by topic, the first part of the volume contains a complete citation for each title. The second part of the volume contains an author index and a short-title index.

\section{Scholar's Guide to Intelligence Literature:}

Bibliography of the Russell J. Bowen Collection.

Price: $\$ 40$ (hardcover). ISBN 0-89093-540-8. Available now.

It is time for intelligence to be taken from the hands of the spy novelists and the sensational headline writers. The bibliography will provide true scholars the basis for the kind of study which intelligence needs.

-William E. Colby

Former Director of Central Intelligence

This is an invaluable reference guide not only for historians, scholars, and students, but for the general reader who wishes to obtain an understanding of the vital role played by intelligence in the history of the United States and in the history of the world as well.

\section{-Dr. Jules Davids \\ Professor of American Diplomatic History \\ Georgetown University}

The Bowen Collection of Intelligence Literature is a wealth of information on a critical but poorly understood dimension of international relations. With the publication of this bibliography, it is now readily available to student and scholar alike, a first-class addition to the field.

-Dr. Graham Allison, Dean

John F. Kennedy School of Government Harvard University

The next best thing to owning one of the greatest collections of works on intelligence is to own this superb bibliography of it-a scholarly guide to the titles that experts consider vital.

\section{UNIVERSITY PUBLICATIONS OF AMERICA 44 North Market Street • Frederick, MD 21701 (301) 694-0100}




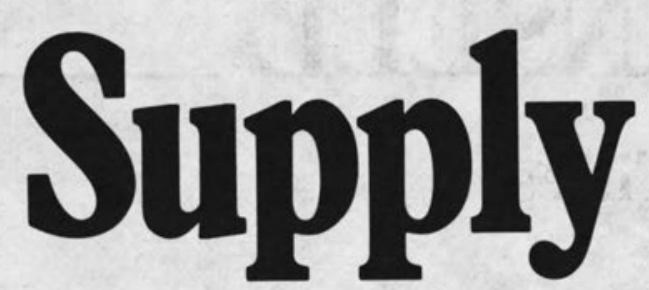

The Goldsmiths'-Kress Library of Economic Literature.

The Goldsmiths'-Kress Library collection is rich in political, social, business,and economic history.

Included in the micropublication are pre-1850 monographs and pre-1906 serials from the Goldsmiths' Library of Economic Literature at the University of London and the Kress Library of Business and Economics at the Harvard Graduate School of Business Administration. Supplemented by materials from Columbia and Yale Universities' libraries, it emerges as the most complete collection of its kind, a major resource for social scientists and historians as well as scholars of business and economics.

To facilitate acquisition, the collection has been restructured and divided into subscription units.

- Customers may now order Goldsmiths'-Kress Library of Economic Literature at our low Standing Order Price of $\$ 1,700-15 \%$ off the Individual Unit Price.

- Call our Academic Order Department or send in the coupon below for more information.

Research Publications 12 Lunar Drive/Drawer AB Woodbridge, CT 06525 (203) $397-2600$

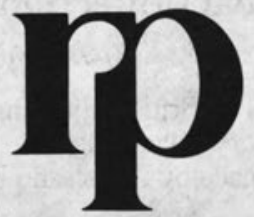

For Europe, Africa \& Asia: Research Publications Ltd. P.O. Box 45

Reading, RG1 8HF England

- Forward more information on the Goldsmiths'-Kress Library of Economic Literature.

- We have begun the collection already, but stopped at Unit Please contact me.

- Send me information on the Consolidated Bibliography, first.

Name

Title

Institution

Address

City State Zip

Phone 


\section{New Titles}

\section{History of Technology, Seventh Annual Volume, 1982}

Edited by A. Rupert Hall and Norman Smith. 152p. 1982. (0-7201-1663-5). \$32.

This annual cumulation of essays focuses on the technical problems confronting different societies and periods and the measures taken to solve them. This year the papers illustrate some of the different ways in which the evidence of historical technology may be approached and handled.

\section{Theses on Islam, Middle East, and North-West Africa 1880-1978}

Compiled by Peter Sluglett. 200p. 1982. (0-7201-1651-1). $\$ 20$.

More than 3,500 theses, submitted for higher degrees at British and Irish Universities, are listed here by region, country, and subject. Each entry gives the author's name, the title of the thesis, the degree for which it was submitted, the university, and year of acceptance.

\section{World Palaeontological Collections}

By R.J. Cleevely. $\quad 450$ p. $\quad 1983 . \quad(0-7201-1655-4) . \quad \$ 75$.

This index, co-published with The British Museum of Natural History, serves as a guide to important natural history collections. The entries cover collections of shells, fossils, insects, and minerals made by British and European naturalists during the past two hundred years.

\section{Geographers: Biobibliographical Studies, Volume 6}

Edited by T.W. Freeman. 152p. 1983. paper. (0-7201-1664-3). \$25.

Published annually, Geographers: Biobibliographical Studies is a compilation of studies of individuals who have made major contributions to the development of geographical thought and of geography as a scientific subject. Volume 6 contains 22 studies which describe the subject's education, life, work, scientific ideas, and the influence and spread of those ideas.

Order directly from:

Mansell Publishing Ltd. 950 University Avenue Bronx, New York 10452 